\title{
Aphids (Aphidae: Homoptera) on "Cacao" in the Dominican Republic ${ }^{1}$
}

\author{
Clyde F. Smith ${ }^{2}$ \\ INTRODUCTION
}

During June of 1955, Dr. L. F. Martorell, Head of the Department of Entomology, Agricultural Experiment Station of the University of Puerto Rico at Río Piedras, collected two species of aphids on "cacao", Theobroma cacao L. in the Dominican Republic. One was Toxoptera aurantiae (Boyer de Fonscolombe). The other, apparently undescribed, is named in honor of L. F. Martorell. I wish to thank D. Hille Ris Lambers of Bennekom, Netherlands, for his opinions concerning this species.

\section{DESCRIPTION}

\section{Macrosiphum Martorelli n. sp.}

This species (fig. $1^{3}$ ) can be recognized by its brilliant yellow-green color: antennal hairs subequal to one-half diameter of base of antennal III; tuberculate sensoria on antennal III of alate vivipara; pale cauda bearing seven hairs; and dark cornicle with a pale base.

\section{Alate Vivipara}

Color of living material brilliant yellow-green. Cleared material: Antennae dark (antennal I and II only dusky); head dusky; legs beyond proximal $1 / 2$ to $2 / 3$ of femora dark; abdomen without pigmented areas; cornicles dark beyond basal 1/10 which is pale; wings with 1st anal and cubitus of forewing with dusky border.

\section{Measurements}

Body length 2.70-2.90; width across eyes $0.53-0.56$; hairs on vertex of head 0.02-0.03; hairs on antennal III, 0.025 (slightly longer than diameter of base of antennal III); antennal III, 0.71-0.85; IV, 0.77-0.87 (antennal IV equal to or slightly longer than antennal III); V, 0.71-0.80; VI, 0.200.22 plus $(0.111+$ broken $)$; rostral IV plus V, 0.14 ; width $0.06-0.07$; hind tibia 2.23-2.38; hind tarsi 0.12-0.13; cornicles 0.69-0.80 (0.15 reticulated); cauda, length $0.31-0.34$, width 0.11 .

1 Contribution from the Entomology Department, North Carolina Agricultural Experiment Station, Raleigh, N. C. Published with the approval of the Director of Research as Paper No. 1072 of the Journal Series.

2 Head, Department of Entomology, North Carolina State College, Raleigh, N. C.

8 Drawings by A. T. Olive. 
Antennal III with 12-14 sensoria; rostrum attaining 2nd coxae; cauda with three lateral hairs and one dorsal hair. First tarsal chaetotaxy 3-3-3. Eighth tergite with four hairs.

\section{Apterous Vivipara}

Color of living and cleared material similar to alate vivipara.

Measurements: Body length 2.40-2.65; width across eyes 0.53-0.54; hairs on vertex of head 0.03 ; hairs on antennal III, 0.03 (equal to $2 / 3$ diameter of base of antennal III); antennal III, 0.87-0.95; IV, 0.75-0.84; V, 0.760.79 ; VI, 0.22 plus $1.42-1.48$; rostral IV plus $\mathrm{V}, 0.13-0.14$; width $0.06-0.07$; hind tibia 2.40; hind tarsi 0.12; cornicles $0.80-0.85$ (reticulated area 0.15 ); cauda, length $0.36-0.40$, width $0.12-0.14$.
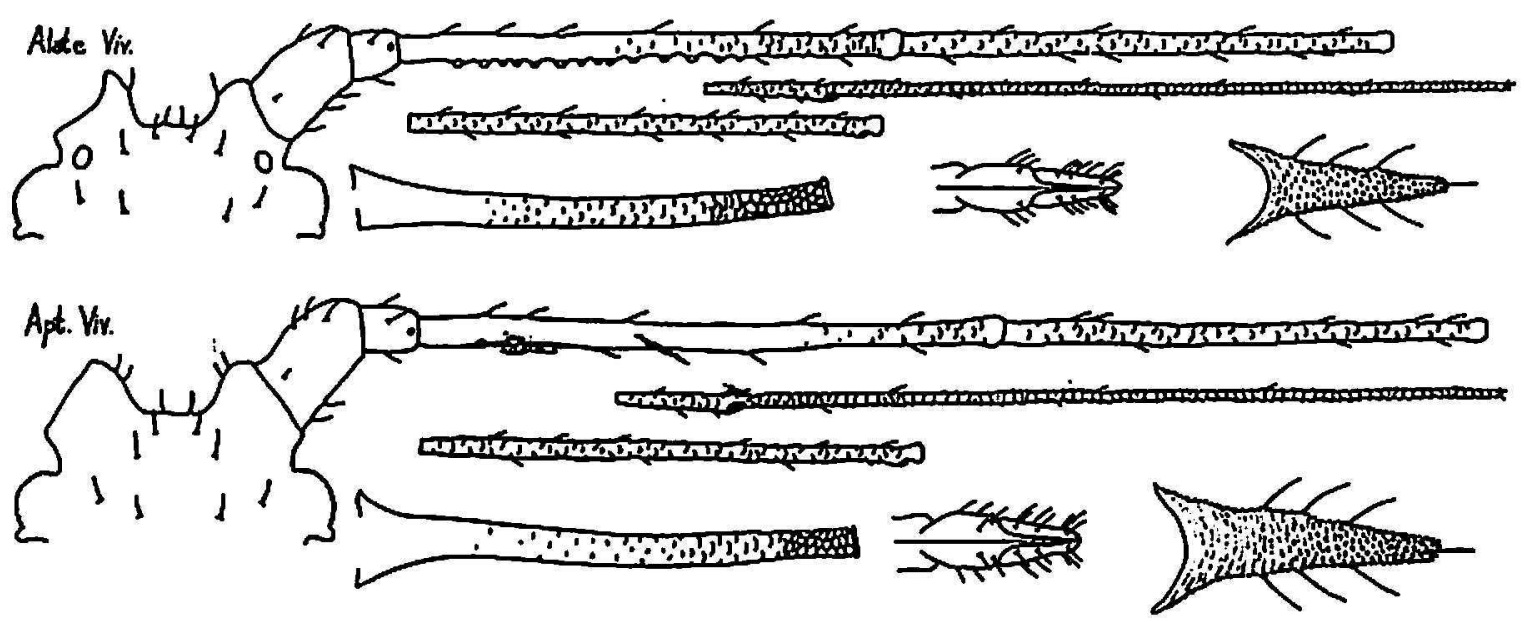

FIa. 1.-Macrosiphum martorelli n. sp.

Antennal III with 1-3 sensoria; rostrum attaining between 2nd and 3d coxae; cauda with three lateral hairs and one dorsal hair; 1st tarsal chaetotaxy 3-3-3. Eighth tergite with four hairs.

\section{Types}

Holotype in U. S. National Museum; paracolonotypes in U. S. National Museum, Agricultural Experiment Station of the University of Puerto Rico, Hille Ris Lamber's collection, and North Carolina State College.

\section{Type Locality}

Dominican Republic, Island of Hispaniola, W. I.

\section{Collections}

On the chocolate tree or "cacao", Theobroma cacao L. in the farm of Pedro Paulino, Sección La Mesa at San Francisco de Macorís, Dominican Republic, June 1955, by L. F. Martorell. Described from the holotype slide 
and nine paracolonotype slides containing a total of 33 specimens. Many of the specimens are in poor condition, lacking parts of legs and antennae.

\section{Economic Importance}

This yellow-green aphid attacks the flowers, young pods and tender foliage of "cacao". The insect lives in association with the "caribe" or fire ant, Solenopsis geminata Fabr. On Pedro Paulino's farm Martorell observed an intense attack of this aphid, also in association with Toxoptera aurantiae causing serious damage, particularly to the tender growth. Wolcott $(1)^{4}$ in 1921 did not observe the insect attacking "cacao" in the Dominican Republic. This insect could be a potential pest of "cacao" in future years and thus it should be considered as such.

\section{SUMMARY}

A new species of aphis, Macrosiphum martorelli is described from the Dominican Republic. This yellow-green aphis attacks the flowers, young buds and tender foliage of "cacao", Theobroma cacao L. causing considerable injuries. Although of no economical importance at present it could be of some importance to the "cacao" industry in the future.

\section{RESUMEN}

Una nueva especie de pulgón, Macrosiphum martorelli, se describe de la República Dominicana. Este pulgón amarillo-verdoso ataca las flores, capullos y follaje tierno del cacao, Theobroma cacao L., y causa daños considerables. Aunque ahorta no es de importancia económica, podría ser de alguna importancia en la industria cacaotera de aquel país en el futuro.

\section{LITERATURE CITED}

1. Wolcott, G. N., Las plagas del cacao en Santo Domingo y algunas indicaciones de cómo combatirlas, Rev. Agr. de P. R. 6(6) 11-2, San Juan, Junio, 30, 1921.

Italic numbers in parentheses refers to Literature Cited, p. 156. 